\title{
18
}

\section{Ecological drift or stable fire cycles in Tasmania: A resolution?}

\section{Ian Thomas}

Department of Resource Management and Geography, Melbourne School of Land and Environments, University of Melbourne, Victoria, Australia

i.thomas@unimelb.edu.au

\section{Phil Cullen}

Natural Resource Planning Pty Ltd, Hobart, Tasmania, Australia

\section{Michael-Shawn Fletcher}

Department of Resource Management and Geography, Melbourne School of Land and Environments, University of Melbourne, Victoria, Australia

\section{Introduction}

On the Central Plateau of Tasmania, up by Liawenee Moor, the wind whistles with frostedged harshness. On the shores of Lake Augusta stood the Bernacchi Training Facility of the Australian Antarctic Division in which generations of bearded heroes listened and learned at the foot of gnarly ice veterans. The main room of the facility was barn-like, with exposed beams, coils of rope and a very large and well-used fireplace. The inside of the chimney was damp, soot blackened and slippery. We know this for a fact because in 1984, Phil Cullen and I (Thomas) were wedged inside, trying to squeeze down into the warmth below. Geoff Hope had sent me up to the plateau to re-sample a small lagoon, which he had previously cored but not analysed. It was my Honours year and I was well chuffed. That Geoff had the confidence to simply say, 'Tasmania, Central Plateau, Liawenee, go' gave me additional heart. That he never once hinted at how I should accomplish the task, I took as a compliment as well. Compliments warm the soul but the taste rarely lingers. Phil and I needed something substantial to eat, and up on the Central Plateau in a snowstorm, we needed shelter. Outside the chimney, all was snow and wind. Inside was food and warmth. There was only one solution. We climbed further down the chimney, fell into the fireplace and pillaged a lifetime supply of freeze-dried pineapple before disappearing into the wild and treeless expanses of Liawenee Moor to extract the cores. Geoff encouraged self-reliance. 
As it turned out, the data threw up the old castanea of stability versus change. For how long had the treeless expanse of Liawenee been treeless? What were the factors that promoted stability? What were the agents of change? What was the balance? Was there a balance? Not many of these thoughts crossed my mind while trapped in the chimney, but later, back at the ANU under Geoff's guiding hand, the data seemed to indicate that for this little part of Tasmania at least, stability was the answer. Basalt soils and frequent frosts conspired to disadvantage any eucalypt which dared to invade the moorland. For perhaps 8000 years or more, Liawenee Moor was almost certainly a treeless grassland interspersed with sub-alpine heaths. At the time of European settlement, the rapid introduction of sheep in large numbers, along with an annual burning regime that favoured dense communities of fire-loving woody heaths, transformed the moor from a grassland to a grassy shrubland. Changes were apparent but not significant enough to alter the treeless state. The moorland was stable in an overall sense and displayed remarkable resilience, primarily due to edaphic controls exerted by clayey basaltic soils.

Over a number of years, Phil and I wandered our way across some of the great landscapes of Tasmania. We thought about succession and fire. We amused ourselves with plans to shatter what we considered 'eco-myths'. Later, Michael Fletcher and I did exactly the same in western Tasmania. Mostly, we thought about Rhys Jones, Bill Jackson and Tony Mount, but we were always guided by the question; Geoff's question. The question can be applied to every landscape in the world, indeed, perhaps to everything in the world. Geoff simply asked his students to always consider why something was here and not there. Biogeography in a nutshell.

Here was the nub of a great ongoing Tasmanian ecological debate and we were walking through the middle of it. The origin of buttongrass plains. The fact that many grasslands and sedgelands are considered to be pyrogenic disclimaxes provided the botanical clue, which linked vegetation change with cultural traditions. Jones $(1968,1975)$ recognised the relationship, and in a brilliant example of synthesis, banished forever the notion that Aborigines were children of nature, incapable of affecting the environment. He introduced to Australia the concept that cultural traditions are inevitably interwoven with ecological processes by way of his famous theory of firestick farming. This advance was accomplished with reference to the equally spectacular botanical work of Jackson $(1965,1968)$, who proposed the first, and so far only, model to explain the nature of the general processes that acted on Tasmanian vegetation during the Holocene.

Alternative theories attracted attention, but failed to win widespread support. Horton (1982) attempted to downplay the effects of Aboriginal fires on the Australian vegetation, but his alternative does not explain the pyrogenic disclimax formations found in Tasmania (Bowman and Brown 1986). Likewise, the static vegetation model of Mount (1979, 1982) does not explain vegetation dynamics on a scale of centuries, much less the longer-term changes determined by pollen analysis (Macphail 1980, 1984, 1988; Colhoun 2000). It is relatively easy to dismiss the arguments of Mount and Horton, especially decadal time scales, but what of Jackson's 'ecological drift', and what happens over centennial and millennial scales? What evidence is out there? Soils, fire and precipitation are the three main factors, but each of these is confounded by local variations and complications. What would Geoff think?

Australia has a history of human occupation which extends for maybe 45,000 to 60,000 years. There has been considerable debate over the exact impact of human activity on the Australian biota over this immense time span. A large body of evidence, gathered from all over the continent, indicates that this impact has been pronounced and largely a result of the regular and sophisticated use of fire by the Aborigines to manipulate their environment (Bowman 1998; Jackson 1999; Lynch et al. 2007). Therefore, an understanding of these impacts and the fire-management practices that produced them should prove very useful in the successful conservation management of many natural ecosystems today. 
Southwest Tasmania provides an appropriate and challenging location to test this approach. The area has a long history of human occupation, with much of the vegetation dependent on fire. Other plant communities, especially those in the alpine zone and those dominated by coniferous species, are extremely fire sensitive and great damage has been caused by wildfires in historical times. Furthermore, many of the major land management problems faced in this region are linked to the current fire regime. These include maintenance of habitat diversity, protection of fire sensitive vegetation and soils, control of fuel build up and wildfire, single species management requirements, and the preservation of what can reasonably be argued to be a cultural landscape.

While it has been or will be possible to conduct research to determine the direct impact of Aboriginal fire regimes on contemporary ecosystems in some parts of Australia (Bowman 1998), this will not be possible in Southwest Tasmania as this knowledge has been lost. However, through careful consideration of the historical records and further research in fields such as ecology, geomorphology, palaeoecology and archaeology, it should be possible to devise sustainable management programs that will conserve this rich and unique environment. In the remainder of this chapter, we provide a brief review of the palaeoecology of southwest Tasmania, present some recent palaeoecological findings and suggest further avenues for research that would provide useful information for the pursuit of this goal.

\section{The environment}

Southwest Tasmania has a cool, temperate maritime climate with high levels of precipitation, evenly distributed throughout the year, relatively low temperatures, and high humidity levels (Genitilli 1972). Snowfalls and frosts can occur in any month, particularly at higher altitudes.

Many people have described the landforms of the region in detail (e.g. Pemberton 1989). Topography varies from low-lying plains to rugged ranges with extremes of aspect and slope. The geology is relatively complex and encompasses considerable variation in bedrock, with Precambrian quartzites dominating and significant exposures of Cambrian volcanics and midPalaeozoic carbonates and clastics. Pleistocene glaciations have shaped the region's erosional landforms, with valley and cirque glacial features evident at higher altitudes. At lower altitudes, deposition forms including outwash tills, and moraines are common (Kiernan 1989). The vegetation of the region is a mosaic of sedgeland-heath, scrub, wet sclerophyll forest and rainforest communities. Alpine vegetation is present on the high peaks and ranges.

Where intact, the soils of the region are dominated by organic horizons. Red/brown fibrous peats overlying mineral soils of varying composition and depth usually occur under forest vegetation. Very dark brown or black fibrous or muck peats overlying sand, gravels and bedrock form large areas of blanket bog (peatland) in the region. These latter soils are found on nutrient-poor Precambrian siliceous substrates which are very slow to weather. They are usually associated with sedgeland-heath and related scrub communities, termed 'moorlands' after the flowering habit of the ubiquitous dominant sedge, buttongrass (Gymnoschoenus sphaerocephalus) (Jarman et al. 1988).

There is more than one million ha of buttongrass moorland in Tasmania (Brown 1999), most of which is found in Southwest Tasmania. The moorlands can be found from sea level to the subalpine zone. The vegetation and underlying soils of these ecosystems have been described in detail by Bowman et al. (1986), Pemberton (1989) and Jarman et al. (1988). Marsden-Smedley (1998) estimates there are around 704,200 ha of moorland and associated scrub communities in this region, accounting for $57 \%$ of the total area. These ecosystems are of considerable conservation significance and represent some of the largest organic terrains in the Southern Hemisphere (Dixon and Duhig 1996). 


\section{Human occupation}

Humans have occupied Tasmania for at least 35,000 years (Flood 1995). Most of the oldest cultural sites on the island are found within southwest Tasmania. Radiocarbon dating of cultural material found in caves here indicates that Aborigines occupied inland areas of the region from around 35,000 to around 12,000 years BP. These caves appear to have been vacated as living quarters after this time. There is an unresolved debate as to whether Aborigines generally abandoned inland southwest Tasmania in the face of advancing wet sclerophyll and rainforest vegetation during the late Pleistocene and early Holocene, or whether they occupied the region throughout the Holocene and until European colonisation (Cosgrove et al. 1990, 1994; Thomas 1993, 1995).

Initial pollen investigations suggested that the vegetation of the region was more open in the late Holocene than before (Macphail 1979), possibly as a result of increased anthropogenic firing under a cooler, dryer climate. Further discovery of dateable cultural deposits in the region may provide an answer to this debate. There are certainly a number of historical records which indicate that Aborigines were living in inland southwest Tasmania in the early 1800s (Binks 1980; Thomas 1993, 1994; Marsden-Smedley 1998). These records demonstrate that people were using fire extensively to modify habitat. European exploration and exploitation of the region resulted in high incidences of wildfire in the region until relatively recent times (Marsden-Smedley 1997b).

\section{Ecological drift versus stable boundaries}

In a vegetation survey of the Florentine River valley, Gilbert (1959) noted that there was a progression from moorland to rainforest through a set of distinct successional stages. This supported the research by Jackson (1958), who proposed that fire was responsible for moorland regeneration. The dependence of buttongrass moorland on fire stands in stark contrast to the ecology of rainforest vegetation, which is highly sensitive to fire (e.g. Jackson 1968 , 1999). Jackson proposed that in the absence of fire, rainforest would displace open moorland. Subsequent work refined this into the 'ecological drift' model, which proposes a predictable set of seral stages in the absence of disturbance.

Overall, Jackson's (1968) model is one in which a succession of communities eventually change to a closed forest community. The model estimates a fire frequency of 10 to 30 years required to maintain an open vegetation community (moorland). As the interval between fires increases, there is an increase in the proportion of woody shrubs. As the fire interval lengthens, taller myrtaceous shrubs, such as Leptospermum and Melaleuca, become more important and wet scrub develops. The longer the fire-free interval, the more chance there is of trees, such as Eucalyptus species, and rainforest undershrubs becoming dominant. A fire-free interval of more than 150 years is sufficient for the development of mixed forest and eventually rainforest. This model holds the incidence of fires as random in space and time.

Mount (1979) agreed with Jackson that fire was important in maintaining vegetation communities. Unlike Jackson, he saw vegetation communities as stable fire climaxes with fixed boundaries. Fire incidence is not random in space and time, according to Mount, but is a reflection of the accumulated fuel loads of each community. As the interval between fires increases, debris accumulates and the risk of fire becomes greater: different decomposition and productivity rates of the plant communities result in differential fuel loads. When adequate fuel is present, a fire will burn, thus resetting the 'fire cycle clock'. Mount placed tentative time limits on his model. Six months was considered sufficient time for fuel accumulation in buttongrass moorlands and 80 years for rainforest (Mount 1979). Neither Jackson nor Mount 
fully appreciated the effects that extreme climatic events such as the fire weather associated with El Nino oscillations have on vegetation.

Nevertheless, the majority of palynological research points to Jackson's model as the truest reflection of western Tasmanian vegetation succession (Macphail 1980). However, there is some confusion here. At the time of Macphail's exemplary and detailed work and bolstered by Colhoun's wide-ranging additions, nearly all pollen diagrams indicated a post-glacial succession of plant communities starting with invasive Eucalyptus and bird-dispersed Phyllocladus. This facilitated the expansion of Nothofagus rainforest between about $9000 \mathrm{yr}$ BP and $6000 \mathrm{yr}$ BP before a climatic deterioration saw the replacement of some rainforest with Eucalyptus forest. Superficially this sounds like succession. It sounds like 'ecological drift'. But the time scales are wrong. According to Jackson, given disturbance free conditions, anywhere in western Tasmania could drift towards and attain rainforest status in as few as 500 years. However, the post-glacial pollen sequences are almost all about 10,000 years long. If they do support ecological drift, then it is a tardy version of what Jackson envisaged and what ecologists can measure over decadal scales.

\section{Pemberton's edaphic model}

The major theme of Pemberton's (1990) alternative model was the relationship between edaphic characteristics and vegetation type. He acknowledges that wet sclerophyll forests are the result of rainforest restricted by fire and that temperature and water availability confines subalpine and alpine plant types to their particular niches. His model differs from the two previous models in his emphasis on soil type and its effect on plant communities. He downplays the role played by fire in the regeneration of buttongrass moorland, favouring the notion that they are natural edaphic disclimaxes.

Edaphic disclimaxes develop on nutrient-poor acidic soils that are waterlogged for most of the year. The harsh environmental restraints placed on plants growing in these areas results in low productivity and slow peat accumulation. According to Pemberton, this is reflected in the normally shallow $(<30 \mathrm{~cm})$ peat profiles of southwest Tasmania. Burning of the moorland inevitably results in peat destruction, and if this occurs during a period of drought, almost total removal of peat results (Brown and Podger 1982; Pemberton 1990).

Colhoun (1996) places importance on factors other than climate in the regression of regional vegetation back towards that seen in the late glacial or early Holocene. A decrease in climate-sensitive rainforest species (namely $N$. cunnghamii) during this phase is seen as an artefact of nutrient leaching in soils and anthropogenic fire. Nutrient leaching is the vehicle driving an increase in the proportion of sclerophyllous species in the vegetation. Sclerophylly promotes flammability, and the build up of fuel loads increased the effectiveness of Aboriginal burning in the region, expediting the expansion of fire-promoted moorland into areas occupied by rainforest (Colhoun 1996; Jackson 1999).

Thomas (1993) noted an obvious lack of local forest over a late-glacial-Holocene pollen sequence from fire-promoted buttongrass moorland at Melaleuca Inlet in the far southwest of the state. The pollen site is in a coastal moorland close to archaeological sites that display continued coastal occupation through the Holocene (Cosgrove 1999). The record clearly displays the usual regional trends in rainforest pollen present in all western Tasmanian pollen records, but the cumulative values of these pollen types never exceeds $20 \%$. Instead, pollen from Ericaceae, Leptospermum, Melaleuca, Gymnoschoenus sphaerocephalus (buttongrass) and Restionaceae dominate and charcoal concentrations are high throughout the sequence (Thomas 1995).

The southwest near-coastal location of this site exposes it to the westerly winds straight off the ocean and the low rainforest pollen content can be partially explained by the lack of forest 
upwind from the site. It is clear, however, that this site was occupied by moorland vegetation throughout the Holocene and that no substantial forest was present at any stage in the c. 12,000-year history recorded at the site. Subsequent analysis of a neighbouring pollen record from the same moorland substantiated this interpretation (M.K. Macphail et al. 1999).

Fletcher (2000) analysed a 10,300-year pollen record from moorland vegetation in the interior of southwest Tasmania and came to the same conclusion as Thomas (1993) and Macphail et al. (1999). Fletcher argued that the area around his site (Harlequin Hill near Lake Pedder) had probably been free of forest vegetation since before Oxygen Isotope Stage (OIS) 2.

Whether human activity pre-set the landscape and whether moorland vegetation was of sufficient flammability to ensure a fire regime that perpetuated this vegetation type and to retard the encroachment of forest, despite a climate hostile to natural lightning-strike fires, is less certain. It is clear from long-term (20-year) vegetation studies and space-for-time analyses that moorland succeeds to forest at different rates depending on moisture, geology, vegetation type, slope, aspect and fire history (Brown and Podger 1982; Marsden-Smedley 1997a, b, 1998; Brown et al. 2002).

The ecological truism is that rainforest will form in any area of western Tasmania given a sufficient fire-free interval. This may not be true. Furthermore, it appears that moorland vegetation 'requires' a fire interval of fewer than 20 years to maintain ecological diversity (Marsden-Smedley and Kirkpatrick 2000). Long fire-free intervals may in some instances result in hot fires fuelled by thick moorland growth (Pemberton 1988, 1989), resulting in sheet erosion and the loss of fire-sensitive communities (Brown et al. 2002).

The results of Balmer (1990) and Marsden-Smedley et al. (1998) indicate that considerably more research is required into vegetation-soil relationships, peat formation and time scales of successional pathways before we can confidently predict the impact of fire on moorland and forest ecosystems.

\section{Peat accumulation and the formation of blanket bogs}

Peat begins to form on a site when the rate of accumulation of organic matter at a site exceeds the rate of decomposition. A cool, moist climate with evenly distributed precipitation throughout the year, low levels of evaporation and nutrient-poor anaerobic soil conditions are conducive to this process. Peat will accumulate in topographic depressions when groundwater tables are high enough to produce soil waterlogging for much of the year. Where precipitation is high enough, soils may remain waterlogged for sufficient time periods for peat accumulation to occur regardless of the groundwater conditions. Peat soils that form under these conditions are called blanket bogs due to the way they blanket the ground surface irrespective of topography. Given sufficiently high and evenly distributed precipitation and low levels of evaporation, blanket bogs can occur on relatively steep slopes.

Blanket bogs are widespread in association with buttongrass moorland in southwest Tasmania. The climatic conditions required for blanket bog development in relation to Tasmania are reviewed by Bridle (1992). Although rainfall is adequate for blanket peat formation (more than $1000 \mathrm{~mm}$ per annum), the temperature regime in southwest Tasmania seems to be slightly higher than the maximum $\left(15^{\circ} \mathrm{C}\right.$ for the warmest month) under which blanket peats form in the Northern Hemisphere. The marginal temperature regime appears to be compensated for by very high and evenly distributed precipitation and high humidity. Although extensive, the blanket bogs of Tasmania are generally shallow compared with those of western Europe and other regions. This fact has led some authors to conclude the climate of western Tasmania is only marginally suitable for blanket bog formation (Jarman et al. 1988). 
Balmer (1990) has suggested that rates of peat accumulation and decay reach equilibrium at around $30 \mathrm{~cm}$ for much of southwest Tasmania. This view is supported by the apparently low rates of peat accumulation in Tasmania. Tasmanian peat accumulation rates have been deduced by examining sediment cores extracted from a variety of peat deposits. They yield accumulation rates of $1-2 \mathrm{~cm} / 100$ years. This is low compared with the $5-6 \mathrm{~cm} / 100$ years recorded for the Northern Hemisphere (Bridle 1992). An alternative hypothesis is that frequent burning episodically vaporises and removes surface peat, with freshly burned and exposed peat surfaces recolonised by adjacent, unburned plant communities. This would almost always result in anomalous age/depth relationships if accumulation rates were based on single basal dates.

\section{The impact of fire on peat soils}

Large areas of blanket bog (in excess of 100,000 ha) have been degraded by fire and subsequent erosion in southwest Tasmania (Pemberton 1988, 1989; Pemberton and Cullen 1995). Much of this degradation is attributed to wildfires started by humans in the recent times. The direct physical effects of fire on peat soils have been summarised in increasing order of severity (Pemberton and Cullen 1995). They are:

1. Removal of some vegetation with no direct impact on the soil.

2. Removal of vegetation which exposes the soil surface, which may then be vulnerable to wind or sheet erosion.

3. Frequent removal of vegetation and litter. Raw material for organic soil development is lost and soil formation is hindered. Ash may be blown or washed away.

4. Removal of vegetation, litter, soil seed bank, and soil to varying depths. Ash may be blown or washed away. The more soil removed, the longer it is likely to take for the soil to reform because of greater stresses on plant development.

5. Soils burned to bedrock, losing thousands of years worth of soil accumulation.

Even low-intensity fires are likely to influence the rate of peat accumulation and it is possible that they may cause peat losses even when peat is not directly burned. Live plant material and litter that accumulates to form peat will be lost. Removal of vegetation cover is likely to result in raised soil temperatures, causing an increase in organic-matter decomposition. Soil water tables may be lowered as a consequence of increased run-off and increased evaporation resulting from higher soil temperatures and airflows over the soil surface, again causing increased organic-matter decomposition. Elsewhere, studies indicate that peatland ecosystems may switch from being net storages of carbon (organic matter) to net sources of carbon (carbon dioxide) with small changes in soil temperature and soil water table position (Shurpali et al.1995; Johnson et al. 1996; Bubier et al. 1999). On the other hand, such effects may be countered by reductions in evapotranspiration until vegetation regrows following the fire. With time, as vegetation reverts to pre-fire condition, conditions conducive to peat accumulation are likely to re-establish.

Clearly vegetation-soil-fire relationships are not well understood and considerable research is required in this area. If the predictions of $\mathrm{CO}_{2}$-induced global warming prove correct, then the consequent climate changes may well have a significant impact on peat accumulation. If the climate of southwest Tasmania is only marginal for blanket bog formation at present, then small shifts in the prevailing conditions, such as a rise in mean annual temperatures, particularly if coupled with inappropriate fire regimes, may well cause blanket peats to degrade. 


\section{Fire regimes in southwest Tasmania}

The association of buttongrass moorland with blanket bog presents an interesting paradox. On one hand, Jackson's (1968) model of 'ecological drift' suggests that moorland vegetation is promoted by, and is resilient to, the impacts of fire, but on the other, the soils that form under this vegetation are readily damaged or destroyed by fire.

Using historical records, Marsden-Smedley (1997b) demonstrates dramatic changes in the fire regime in southwest Tasmania in the past 170 years. He proposes that the pre-European fire regime was one of frequent, low-intensity, small-scale burns used by the Aborigines for habitat management. From the 1850 s to the 1930 s, the fire regime was one of less frequent, high-intensity, 'landscape-scale' wildfires. From the 1940s to the 1960s, the fire regime was one of medium intensity in spring and autumn. Since the 1970s, there has been a policy of fire exclusion from virtually all of the area. Burning has been largely restricted to small fuelreduction fires at a few localities, but there have been a few notable exceptions.

Most of the degraded peatland evident on aerial photographs and satellite images falls within the boundaries of fires that have occurred in the region since the 1930s (Cullen unpublished data and fire boundaries mapped by Marsden-Smedley 1997). There also have been dramatic losses of fire-sensitive vegetation in the region in historical times (Cullen and Kirkpatrick 1987; Brown 1988; Gibson and Brown 1991).

The fact that fire-sensitive ecosystems were significantly more widespread before the arrival of Europeans suggests that the burning practices of the Aborigines were sophisticated (Bowman and Brown 1986; Cullen and Kirkpatrick 1987; Thomas 1993; Thomas and Hope 1994; Bowman 1998; Bird et al. 2008). This is not to say that burning by Aborigines did not cause damage to vegetation or organic soils. At Melaleuca, small peat fires during the middle Holocene caused the removal of blanket peat (Macphail et al. 1999), while in the Denison Range, there is clear evidence that plant communities dominated by native pines were severely affected by fires which may have been induced by Aborigines. However, for blanket bogs to form, moorland ecosystems must act as net stores/sinks of carbon (organic matter). This implies that the climate and Aboriginal fire regime over the Holocene has been conducive to peat accumulation, even if rates seem somewhat retarded compared with the Northern Hemisphere. At present, we have little knowledge of Aboriginal occupation and use of fire in southwest Tasmania throughout the Holocene. Future research in this field will depend on detailed research into the ecology, palaeoecology and archaeology of the region.

\section{Buttongrass moorland during the late Pleistocene and Holocene}

Pollen sequences obtained from bogs and lakes indicate that the vegetation of lowland southwest Tasmania during the last glacial was open and herbaceous, with alpine and subalpine affinities (see the review in Jackson 1999). By the early to middle Holocene, there is an increasing dominance of pollen associated with closed forest communities. A warmer, wetter climate during the period 9000 to 6000 years ago appears to have favoured the spread of this vegetation. During the late Holocene, decreasing temperatures and precipitation produced an opening of forest vegetation (Macphail 1980), accompanied by increases in charcoal particles in the deposits. This may indicate greater deliberate burning activity by the Aborigines and/or increases in the occurrence of wildfires.

However, pollen evidence from all pollen sites in the southwest indicates that the longterm successional sequence proposed by Jackson does not adequately explain the persistence of buttongrass moorlands for the entire length of the Holocene if people have been largely absent from the southwest during the Holocene. 
Colhoun et al. (1991) found fairly consistent levels of charcoal associated with pollen representing a range of vegetation assemblages throughout the Holocene at Govenor Bog in the King River valley and concluded that fire was 'an ever-present ecological factor of the changing alpine, subalpine, temperate vegetation/environmental changes'. It seems likely that at least some of this firing would have resulted from human ignition sources.

Two pollen sequences from Melaleuca in the far southwest provide vegetation records that span the Holocene (Thomas 1995a; Macphail et.al. 1999). These show the persistence of open moorland vegetation and blanket bog from the late Pleistocene until the present in a location that is at low altitude and relatively close to the present coast. Both sequences show that fire was present in the environment throughout this time. Macphail et al. (1999) interpret a hiatus in the sedimentary record as evidence of a peat-burning fire. In addition, neither site provides evidence that the far southwestern coastal plains formed refugia for arboreal taxa. Nor do they indicate any long-term successional changes from moorland to forest. However, the sequences indicate that Gymnoschoenus sedgeland coexisted with Poa grassland at the end of the last glacial under conditions where fire was present but far less significant than at any subsequent time. In other words, moorland was able to prosper under conditions of both high and low fire pressure (where intensities and frequencies are as yet unknown). If Jackson's model is appropriate and general, the early Holocene should have been a phase of forest expansion similar to the sites investigated by Macphail $(1979,1980)$. This inconsistency can be resolved by postulating a late last glacial to early Holocene phase in the southwest in which environmental perturbation was not fire but something else, possibly soil instability or increased soil infiltration rates.

A third sequence from the inland southwest taken from a buttongrass moorland near the foot of Mount Anne near the present Lake Pedder also indicates that buttongrass communities have dominated from at least the late last glacial right up to the present day (Fletcher and Thomas 2007a, b). By analysing pollen transport and depositional processes, it was possible to demonstrate that Gymnoschoenus pollen, although abundant in the landscape, is rarely presented in pollen diagrams. This has resulted in a severe under-representation of the single major plant association in western Tasmania. When regionally significant pollen types are subtracted from pollen sums, the true nature of local and extra-local plant communities is revealed. These have uniformly been found to be treeless plant communities which have existed for at least the entire Holocene.

This point needs to be reiterated: no moorland site in southwest Tasmania contains pollen values (Thomas 1995a; Fletcher and Thomas 2007b) which indicate the former presence of rainforest on site. It is also clear that areas occupied by closed forest associations today have been forested since the termination of the Last Glacial Maximum. This interpretation is supported by a supplementary meta-ordination of all late glacial and Holocene pollen samples from western Tasmania (Fletcher 2007a). No change in the overall relative proportions of major plant community types compared with that seen today is visible in any pollen record for this period.

\section{Conclusions}

It seems that both Tony Mount and Bill Jackson were right. Jackson's 'ecological drift' is rightly seen as the model which best explains changes at decadal and centennial time scales, especially in the ecotones of plant communities in the western Tasmania. Mount's 'stable fire cycle' model cannot explain floristic changes that are demonstrably measurable, either in real time or by space-for-time substitution. However, the data shows quite clearly that major expanses of buttongrass have remained treeless for at least 10,000 years and so stability rather than change is the overriding feature on sub-regional and regional scales. The only way in 
which Jackson's model can operate over the long time scales involved is to invoke either or both fire and subsequent edaphic modification. However, if fire pressure was so great that a constant state of disclimax was achieved, then we return to a situation where stability is the key and Mount's 'stable fire cycle' model seems rather more attractive than it does for shorter time scales. In other words, scale dependency is paramount.

A great amount of knowledge relevant to current management of southwest Tasmania was lost with the passing of Aboriginal occupation of the region. At present, we have very limited information on which to base future management practices. The extensive losses of fire-sensitive vegetation and organic soils in the region in recent times demonstrate that if we are to manage southwest Tasmania in a sustainable manner, we must proceed with caution. As concluded by Bowman and Brown (1986), experimental investigations and manipulation of fire regimes in association with appropriate palynological studies are likely to provide the best solutions to these problems.

\section{References}

Balmer, J. 1990. Two moorland boundaries. Tasforests 1:133-141.

Binks, C.J. 1980. Explorers of Western Tasmania. Launceston, Tasmania: Mary Fisher Bookshop. Bliege Bird, R., D.W. Bird, B.F. Codding, C.H. Parker and J.H. Jones 2008. The fire stick farming hypothesis: Australian Aboriginal foraging strategies, biodiversity, and anthropogenic fire mosaics Proceedings of the National Academy of Science 105:14796-1480.

Bowman, D.J.M.S. 1998. Tansley Review No. 101: The impact of Aboriginal landscape burning on the Australian biota. New Phytologist 140:385-410.

Bowman, D.M.J.S. and M.J. Brown 1986. Bushfires in Tasmania: a botanical approach to anthropological questions. Archaeology in Oceana 21:166-171.

Bowman, D.J.M.S. and W.D. Jackson 1981. Vegetation succession in Southwest Tasmania. Search 12:358-362.

Bowman, D.J.M.S., A.R. MacLean and J.K. Crowden 1986. Vegetation-soil relations in the lowlands of southwest Tasmania. Australian Journal of Ecology 11:141-153.

Bridle, K. 1992. Organic soils on Mt Sprent, south west Tasmania: an analysis of correlations with local climate, microtopography and vegetation. Unpublished Master of Environmental Studies thesis, Department Geography and Environmental Studies, University of Tasmania.

Brown, M.J. 1988. The distribution and conservation of King Billy Pine. Forestry Commision, Tasmania.

Brown, M.J. 1999. Buttongrass moorlands. In Reid, J., R.S. Hill, M.J. Brown, and M.J. Hovenden (eds) Vegetation of Tasmania. Flora of Australia Supplementary Series, Volume 8, pp286-303. Australian Biological Resources Study, Canberra.

Brown, M.J. and F.D. Podger 1982. Floristics and fire regimes of a vegetation sequence from sedgeland-heath to rainforest at Bathurst Harbour. Australian Journal of Botany 30:659-676.

Bubier, J.L., S. Frolking, P.M. Crill and E. Linder 1999. Net ecosystem productivity and its uncertainty in a diverse boreal peatland. Journal of Geophysical Research 104(D22):27638-27692.

Colhoun, E.A. 2000. Vegetation and climate during the Last Interglacial-Glacial cycle in western Tasmania, Australia. PalaeogeogrAphy, Palaeoclimatology, Palaeoecology 155, 195-209.

Colhoun, E.A., G. van de Geer and S.J. Fitzsimons 1991. Late glacial and Holocene vegetation history at the Governors Bog, King Valley, western Tasmania, Australia. Journal of Quaternary Science 6:55-66.

Cosgrove, R., J. Allan and B. Marshall 1990. Palaeo-ecology and Pleistocene human occupation in south central Tasmania. Antiquity 64:59-78. 
Cosgrove, R., J. Allan and B. Marshall 1994. Late Pleistocene human occupation in Tasmania: a reply to Thomas. Australian Archaeology 38:28-35.

Cullen, P.J. and J.B. Kirkpatrick 1987. The ecology, distribution and conservation of Athrotaxis: A report to the Australian Heritage Commission. Tasmanian Conservation Trust and Department of Geography and Environmental Studies, University of Tasmania.

Dixon, G. and N. Duhig 1996. Compilation and assessment of some places of geoconservation significance. Report to the Tasmanian RFA Environment and Heritage Committee.

Fletcher, M.S. and I. Thomas 2007a. Modern pollen-vegetation relationships in western Tasmania. Review of Palaeobotany and Palynology 146:146-168.

Fletcher, M.S. and I. Thomas 2007b. Holocene vegetation and climate change from near Lake Pedder, south-west Tasmania, Australia. Journal of Biogeography 34(4):665-677.

Flood, J. 1995. Archaeology of the dreamtime. The story of prehistoric Australia and its people. Australia: Angus and Robertson.

Gentilli, J. 1972. Australian climatic patterns. Melbourne, Victoria: Nelson.

Gibson, N. and M.J. Brown 1991. The ecology of Lagarostrobos franklinii (Hook.f.) Quinn (Podocarpaceae) in Tasmania. 2. Population structure and spatial pattern. Australian Journal of Ecology 16:223-229.

Gilbert, J.M. 1959. Forest Succession in the Florentine Valley, Tasmania. Papers and Proceedings of the Royal Society of Tasmania. 93:129-151.

Horton, D. 1982. The burning question: Aborigines, fire and Australian ecosystems. Mankind 13(3):237-251.

Jackson, W.D. 1965. Vegetation. In J.L. Davies (ed.) Atlas of Tasmania, pp30-35. Hobart: Mercury Press.,

Jackson, W.D. 1968. Fire, air, water and earth-an elemental ecology of Tasmania. Proceedings of the Ecological Society of Australia 3:9-16.

Jackson, W.D. 1999. The Tasmanian Environment. In J. Reid, R.S. Hill, M.J. Brown and M.J. Hovenden (eds) Vegetation of Tasmania. Flora of Australia Supplementary Series 8, pp11-38. Australian Biological Resources Study, Canberra.

Jackson, W.D. 1999. Palaeohistory of vegetation change: The last 2 million years. In J. Reid, R.S. Hill, M.J. Brown and M.J. Hovenden (eds) Vegetation of Tasmania. Flora of Australia Supplementary Series 8, pp286-303. Australian Biological Resources Study, Canberra.

Jarman, S.J., G. Kantvilas and M.J. Brown 1988. Buttongrass moorlands in Tasmania. Tasmanian Forestry Research Council Research Report No 2, Hobart, Tasmania.

Johnson, L.C., G.R. Shaver, A.E. Giblin, K.J. Nadelhoffer, E.R. Rasetter, J.A. Laundre and G.L. Murray 1996. Effects of drainage and temperature on carbon balance of tussock tundra microcosms. Oecologia 108:737-748.

Jones, R. 1969. Fire stick farming. Australian Natural History 16:224-8.

Jones, R. 1975. The neolithic, paleolithic and the hunting gardeners: man and land in the Antipodes. In R.P. Suggate and M.M. Cresswell (eds) Quaternary Studies, pp21-34. Wellington: Royal Society of New Zealand.

Kiernan, K. 1989. Multiple glaciation of the upper Franklin Valley, Western Tasmania Wilderness World Heritage Area. Australian Geographical Studies 27(2):208-233.

Lynch A., H., J. Beringer, P. Kershaw, A. Marshall, S. Mooney and N. Tapper 2007. Using the palaeorecord to evaluate climate and fire interactions in Australia. Annual Review of Earth and Planetary Science 35:215-39.

Macphail, M.K. 1979. Vegetation and climates in Southern Tasmania since the last glaciation. Quaternary Research 11:306-341.

Macphail, M.K. 1980. Natural regeneration processes in Tasmanian forests: a long-term perspective based on pollen analysis. Search 11:184-190.

Macphail, M.K., Pemberton, M. and Jacobson, G. 1999. Peat mounds of southwest Tasmania: possible origins. Australian Journal of Earth Science 46:667-677. 
Marsden-Smedley, J.B. 1997a. Fire and fuel in Tasmanian buttongrass moorlands: regimes, characteristics, behavior and management. Unpublished $\mathrm{PhD}$ thesis, Department of Geography and Environmental Studies, University of Tasmania, Hobart, Tasmania.

Marsden-Smedley, J.B. 1997b. Fire regimes in southwest Tasmania: implications for management. Unpublished paper, Department of Geography and Environmental Studies, University of Tasmania.

Marsden-Smedley, J.B. 1998. Changes in southwestern Tasmanian fire regimes since the early 1800's. Papers and Proceedings of the Royal Society of Tasmania 132:15-29.

Marsden-Smedley, J.B. and J.B. Kirkpatrick 2000. Fire management in Tasmania’s Wilderness World Heritage Area: ecosystem restoration using Indigenous-style fire regimes? Ecological Management and Restoration 1:195-203.

Mount, A.B. 1979. Natural regeneration processes in Tasmanian forests. Search 10:180-6.

Mount, A.B. 1982. Fire-cycles or succession in south-west Tasmania. Search 13:174.

Pemberton, M. 1988. Soil erosion between Birches Inlet and Elliot Bay. Papers and Proceedings of the Royal Society of Tasmania 122:109-114.

Pemberton, M. 1989. Land systems survey of Tasmania Region 7- Southwest. Department of Agriculture, Tasmania.

Pemberton, M. and P. Cullen 1995. Impacts of fire on soils in Tasmania. In Bushfire '95: Australian Bushfire Conference 27-30 September 1995, Hobart, Tasmania.

Shurpali, N.J., S.B. Verma and J. Kim 1995. Carbon dioxide exchange in a peatland ecosystem. Journal of Geophysical Research 100(D7):14319-14326.

Thomas, I. 1993. Late Pleistocene environments and Aboriginal settlement patterns in Tasmania. Australian Archaeology 36:1-11.

Thomas, I. 1995a. Where has all the forest gone: new pollen evidence from Melaleuca Inlet, SW Tasmania. In G. Dixon and G. Aitken (eds) Proceedings of Institute of Australian Geographers 1993 Conference pp295-301. Monash University Publications in Geography 45. Melbourne: Monash University.

Thomas, I. 1995b. Models and Prima-donnas in southwest Tasmania. Australian Archaeology 41:21-23.

Thomas, I. and G.S. Hope 1994. An example of Holocene vegetation stability from Cameron's Lagoon, a near treeline site on the Central plateau, Tasmania. Australian Journal of Ecology 19:150-158. 